E-ISSN: 1308-8505

Geliş Tarihi: 27.01.2019
Kabul Tarihi: 25.06.2020

YIL: 2020

Online Yayın: 29.06.2020

ÖZGÜN ARAŞTIRMA
Cilt: 35 Sayı: 2 Sayfa: 431-443

Doi: 10.24988/ije.202035215

\title{
Y Kuşağı Çalışanlarının İşe Alınması ve İşte Tutulması için İnsan Kaynakları Stratejileri*
}

\author{
Şerife UĞUZ ARSU 1 , Mehmet Halit YILDIRIM 2 \\ Özet
}

Bu çalışmanın amacı, günümüz işletmelerinin çoğunluğunu oluşturması ve gelecekte iş dünyasının şekillenmesine büyük katkı sağlayacak olması nedeniyle etkili uygulamalara ihtiyaç duyacak olan insan kaynakları ve yöneticilerine, en hızlı büyüyen iş gücü, iş hayatına girmeye başlayan en son kuşak grubu olan ve diğer kuşaklardan farklı olarak iş hayatından yüksek beklentileri olan $Y$ kuşağını işe alma ve işte tutma konusunda ne gibi stratejilere ihtiyaç duyacaklarını ve motivasyonu etkileyen unsurların bu stratejiler üzerindeki etkisini incelemektir. Araştırma amacıyla, Gaziantep ilinde Sanayi ve Ticaret Odasına kayıtlı 80 büyük ölçekli işletmeden 46'sında yer alan 100 insan kaynakları yönetici ve yetkilisine, literatür ışığında hazırlanan anketler uygulanmıștır. Araştırma sonucunda, Y kuşağının motivasyonunu etkileyen "iş yaşam dengesi, eğitim fırsatları ve takım çalışması", "liderlik ve danışma programları" ve "sorumluluk alma" alt boyutları, onları işe alma ve işte tutma stratejileri üzerinde etkisi olduğu görülmüştür.

Anahtar kelimeler: Y Kuşağı, Motivasyon, İşe Alma, İşte Tutma, IK Yöneticileri

Jel Kodu: M54, M12

\section{Human Resources Strategies for the Recruitment and Retention of Generation Y Employees}

\section{Abstract}

This study investigated the potential strategies and related motivation factors that are required for the recruitment and retention of Generation $Y$, which is the fastest growing segment of today's workforce that has higher expectations compared to previous generations. As Generation Y forms the majority of today's businesses and will have a significant role in shaping the future business world, managers and human resource specialists need effective strategic plans to attract this generation to their business. A survey prepared in the light of the studies in the literature was conducted on 100 human resources specialists and managers from 46 large-scale enterprises registered to the Gaziantep Chamber of Industry and Commerce. The study determined that the work-life balance, training opportunities and team work sub dimension, the leadership and mentoring programs sub dimension and the taking responsibility sub dimension, which motivate Generation $Y$, have effects on the strategies for the recruiting and retention of Generation $Y$.

Keywords: Generation Y, Motivation, Recruitment, Retention, HR Managers

Jel Codes: M54, M12

\section{INTRODUCTION}

Today, the baby boomer generation has retired, Generation X is shaping the work environment and Generation $Y$ is the fastest-growing workforce and the latest generation to join the business life (Martin and Tulgan, 2006; Als, 2008). With the retirement of the baby boomer generation, a great vacancy appeared in the workforce. Generation X, which is smaller in population compared to the boomers, was unable to bridge this gap. Thus, Generation Y, which is a lot bigger in population compared to Generation X will enter the workforce to bridge the human power gap and will constitute the majority of the total workforce (Ricks, 2010). Generation Y, which integrates the approach Generation $X$ has towards technology, the traditionalists' efforts to do the best and the teamwork ethics of the baby boomers, is the

\footnotetext{
* Bu çalışma Aksaray Üniversitesi, Sosyal Bilimler Enstitüsü, İşletme Anabilim Dalında 24.06.2014 tarihinde savunulan Şerife UĞUZ ARSU'nun yüksek lisans tezinden türetilmiştir.

ATIF ÖNERÍsí (APA): Uğuz Arsu, Ş., Yıldırım, M. H. (2020). Human resources strategies for the recruitment and retention of generation Y employees. İzmir İktisat Dergisi. 35(2). 431-443. Doi: 10.24988/ije.202035215

${ }^{1}$ Araş. Gör., Aksaray Üniversitesi, İktisadi ve İdari Bilimler Fakültesi, Merkez / AKSARAY, serifeuguz@gmail.com ORCID: 0000-0002-7922-4597

2 Dr. Öğr. Üyesi, Aksaray Üniversitesi, İktisadi ve İdari Bilimler Fakültesi, Merkez / AKSARAY, yildirimmh@gmail.com ORCID: 0000-0002-7001-5705
} 


\section{Ş. UĞUZ ARSU- M. H. YILDIRIM}

best workforce to have entered the business world up until now (Nicholas, 2008). Thus, in order to sustain a successful business, employers will need effective practices to attract, retain and manage Generation $Y$, who have different characteristics compared to other generations, look for more than a stable job, challenge existing work values and consider quitting their jobs if they're not satisfied with the workplace (Chao and Gardner, 2008). However, before employers can identify human resources (HR) strategies to attract and retain Generation $Y$, they must get to know this generation.

In this regard, this study aimed to determine the elements that affect the motivation of Generation $Y$ in terms of recruitment and retention strategies. In line with this aim, questionnaires were distributed to managers and employees working in the HR departments of firms registered to the Gaziantep Chamber of Industry and Commerce to determine what they paid attention to when recruiting Generation Y, which practices they used to retain Generation Y and what kind of strategies they adopt regarding this generation. The collected data were analyzed by using the model developed in the study.

\section{CONCEPTUAL FRAMEWORK}

\subsection{Generation $Y$}

Generation Y, also known as the Millennial Generation, are those born between the years of 1979 and 1994. They are the children of Generation X, namely the Baby Boomers, who were born between 1964 and 1970 (capital.com.tr, 2000). According to Senbir (2004), Generation Y are the children of the years when computer and GSM technologies were first introduced and a technologyfriendly, individual, comfortable world began to globalize. Although they are individualistic, they are a generation that bears the reflection of the souls of the contended and idealist Generation X, who are their elder brothers and sisters. Today, the Pre-Y Generation are especially significant as they are the fathers and mothers of Generation Z.
The earliest date for the beginning of Generation $Y$ is defined as 1977, while the latest is 1981. The earliest date for the end of the generation, however, is defined as 1994 and the latest is 2002 (Tolbize, 2008; Brown et al., 2009). Likewise, according to various researchers in the literature, this generation involves people born between the years of 1980 and 2000 (Zemke, 2000), 1982-1991 (Oblinger and Oblinger, 2005); 1978-1999 (Martin and Tulgan, 2006); 1982-2000 (Lancaster, 2004); 1981-2000 (Reeves and Oh, 2008); 1977-1994 (Broadbridge et al., 2007); 1980-2005 (Heinig, 2009).

Generation Y has been dubbed the Internet Generation, 2011 Generation, Einstein Generation, Next Generation, www Generation, Digital Generation, Dot.com Generation, Net Generation, Hybrid Generation, Echo Boom Generation, Post-80s Generation and MySpace Generation (Zemke et al., 2000; Buahene and Kovary, 2003; Senbir, 2004; Martin, 2005; Oblinger and Oblinger, 2005; Martin and Tulgan, 2006; Yan, 2006; Murphy, 2007; Broadbridge et al., 2007; Tolbize, 2008; Behrstock and Clifford, 2009; Sullivan et al., 2009; Valley, 2010; Kandelousi and Seong, 2011; cargill.com.tr, 2013). Some members of Generation Y are called Echo Boomers as they are the children of the Baby Boomers Generation. In addition, Generation Y has been called the Net Generation on account of the influences of the rapid development in digital technology (Lancaster, 2004; Huybers, 2011).

The term Millennial Generation is used for Generation $\mathrm{Y}$ as this generation involves the developmental years of the beginning of the new century and in order to identify the young people who grew up exposed to sensory invasion by digital technology and tools of mass communication (Lancaster, 2004; Huybers, 2011: 16). The term Generation Y first appeared in the lead article of the Advertising Age magazine, which focused on the data analysis of marketing and media in order to define the people born between the years of 1980 and 1993 (Schlitzkus et al., 2010). 
Lancaster (2004) indicate that since then, the scale of this term has been developed as maximum 2000 and minimum 1982. It is also suggested that this generation is called the Why Generation (Chester, 2002), which is shortly spelled "Y" (Arman, 2013), as they question everything. In addition, Generation $\mathrm{Y}$ have called themselves various names such as the Nuclear-free Family Generation, Imitators, Good Feeling Generation, Cyber/Virtual Children, Do or Die Generation and Identity Search Generation (Martin, 2005; Tolbize, 2008; Srnivasan, 2012).

\subsection{Workplace Characteristics of Generation Y}

Life is rarely straight forward and in order in the 21st century. Traditionally, first the education stage is completed, then working life begins and after that comes either career change or retirement. However, the life of Generation $\mathrm{Y}$ is more different with various careers, roles and stages. Today, education in the life of Generation $Y$ continues until adulthood and then expands into multiple careers and retraining throughout their whole life (McCrindle Research, 2006). Thus, Generation Y has several requirements from a workplace. Those are receiving financial rewards after completing a given task, entertainment, social relations, training, personal development, satisfaction and environmental sustainability (McCrindle Research, 2006). Research suggests that Generation Y demands the most from working life (GWI, 2010; Yüksekbilgili, 2013).

Generation $Y$ is different from the previous generations in many respects. One of these differences is their work ethic. The main characteristics that Generation Y demands in a workplace are an enjoyable working atmosphere, non-financial additional payments and flexible working hours (Cole et al., 2002). Some resources have collected the fundamental motivational factors that Generation $Y$ considers important regarding work and career under certain titles. However, the general factors that are common among all are self- development, work/life balance, proving oneself and taking responsibility, good management and managerial style, being rewarded, competitive salary, working atmosphere and workplace culture, career development opportunities, constant learning and team-oriented working (McCrindle Research, 2006; NAS, 2006; NAS, 2007; Karefalk et al., 2007; Felix, 2007; Glass, 2007; Cruz, 2007; MonsterTRAK, 2008; Meier and Crocker, 2010; Keleş, 2011). In this context, members of generation $Y$ transfer their aforementioned characteristic features into the work environment. The relevant literature suggests that the most fundamental workplace features that bear the characteristic features of Generation Y are as follows: Good Management and Ideal Manager: McCrindle Research (2006); RHI (2007); Rolljsö (2008); Crampton and Hodge (2009), Work Environment: Cole et al.(2002); RHI (2007); Deloitte (2007); Yeaton (2008); Datta Gupta and Christensen (2008); Meier and Crocker (2010); Hoff (2010), Trust and Loyalty towards the Organization: Martin and Tulgan (2006); Karefalk et al. (2007); Hastings (2007); Als (2008); Hewlett et al. (2009); Huybers (2011); Mukundan et al. (2013), Leadership Styles: Dulin (2008), Communication and Feedback: Spiro (2006); Hart (2006); Cruz (2007); Rollsjö (2008); Crampton and Hodge (2009); Fox (2011); Jokela (2012), Work/Life Balance and Flexibility: RHI (2007); Deloitte (2007); Yeaton (2008); Rollsjö (2008); Crampton and Hodge (2009); Twenge et al. (2010); Huybers (2011); D'Netto (2011), Team Work: Cole (2002); Buanhe and Kovary (2003); Martin (2005); Spiro (2006), Performance, Salary and Rewards: Martin and Tulgan (2006); Martin (2005); Jones et al. (2005); RHI (2007); Deloitte (2007); Rollsjö (2008); MonsterTRAK (2008); Meier and Crocker (2010); Naidoo (2010), Motivation: Oliver (2006); Hulett (2006); Glass (2007); Sayers (2007); Cheese (2007); Yeaton (2008); Twenge and Campbell (2008); Lowe et al. (2008); Blain (2008); Kim et al. (2009); Meier and Crocker (2010); D'Netto (2011); Luscombe et al. (2013), Personal and 
Professional Development Opportunities and Career Expectations: Deloitte (2007); RHI (2007); Jokela (2012).

\subsection{Strategies of Recruitment and Retention of Generation Y}

Recruitment and retention have been a source of anxiety for both employers and HR managers for years due to the fact that they are crucial elements for organizational success (Zhao, 2006). Organizations have been using various tech-savvy methods to attract potential Generation Y employees (Schlitzkus et al., 2010). These methods are summarized below: Internet: MonsterTRAK (2008); Als (2008), Website: Als (2008), Social Networks: Schlitzkus et al. (2010); Roy and Kreiss (2011), Media: Als (2008); The Millennial Impact Report (2013), Advertising and Promotion: Mccrindle Research (2006), Smart Phone: The Millennial Impact Report (2013), Electronic Mail: The Millennial Impact Report (2013).

Many HR managers endeavor to carry out practices devoted to the expectations of Generation Y. However, there is limited literature on how Generation Y can be managed (Crampton and Hodge, 2009). recruitment and retention strategies have been identified in the studies and reports carried out to find solutions to the problems regarding the management of Generation Y such as recruitment, retention and employee turnover rate. The studies that examined these strategies were conducted by Zemke et al. (2000); Martin and Tulgan (2001); Chester (2002); Hulett (2006); McCrindle Research (2006); NAS Recruitment Communications (2006); Martin and Tulgan (2006); Murphy (2007); Cheese (2007); Sayers (2007); Salt (2007); RHI (2007); Reynolds et al.(2008); SHRM (2009); Behrstock and Clifford (2009); Roy and Kreiss (2011). However, these strategies will not be addressed in detail in this study, instead, the findings of the study and these strategies will be compared in the conclusion part.

\section{METHODOLOGY}

The aim of this study was to examine the effects of the factors impacting the motivation of Generation $Y$ on the strategies of recruiting and retention of Generation Y. Within this context, the 19 question Scale of the Factors Affecting the Motivation of Generation Y (cronbach's alpha=0,854), 12 question Scale of the Strategies for the Recruitment of Generation Y (cronbach's alpha $=0,897$ ) and 18 question Scale of Strategies for the Retention of Generation Y (cronbach's alpha $=0,924$ ), all of which were given in the survey of the study of Huybers (2011) titled "The Recruitment and Retention of Generation Y", were used. When the cronbach's alpha coefficients, which were achieved as a result of the reliability analyses applied to the scales, were reviewed it was determined that the reliability of the scales were at acceptable levels. In addition, one of the questions in the Scale of the Factors Affecting the Motivation of Generation Y could not be answered by most of the participants, thus, it was excluded from the scale and the analysis was carried out with 18 questions.

According to the literature, Generation Y stands out as the generation that is harder to motivate compared to other generations and has different expectations from workplaces. Thus, in this study, it was aimed to define what kind of strategies businesses could use to recruit and retain Generation Y and what kind of effects the motivating factors had on these strategies. In the literature, despite the fact that the factors increasing the motivation of Generation $Y$ were measured with different scales, in general each factor was investigated in sub-dimensions instead of being investigated separately. Additionally, in this study, factor analysis was performed and the sub dimensions of the motivating elements were named. The recruitment and retention scales were examined as dependent variable, thus, they were not subjected to factor analysis and were examined in single dimension. In light of this information, the effects of the sub dimensions of the Scale of the Factors Affecting the 
Motivation of Generation Y on the retention and recruitment strategies were included in the research model created in this study. Figure 1 presents the model created.

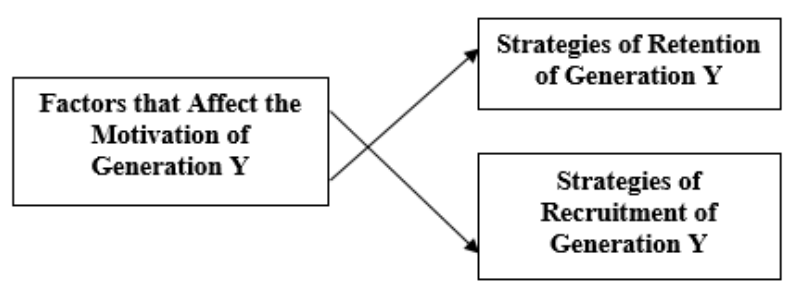

Figure 1: Model of the Study

In order to test the research hypotheses formed according to the research model, primarily factor analysis was applied on the Scale of the Factors Affecting the Motivation of Generation $\mathrm{Y}$ to determine its sub dimensions. Multiple regression analysis was performed in order to determine the effects of the named sub dimensions on the strategies of recruitment and retention. The hypotheses defined to realize the aim of this study are given below.

\section{Hypotheses of the Study}

- $\mathrm{H}_{1}=$ Sub-dimensions of the factors that affect the motivation of Generation Y affect the strategies for the recruitment of Generation Y

- $\mathrm{H}_{2}=$ Sub-dimensions of the factors that affect the motivation of Generation Y affect the strategies for the retention of Generation Y

This study was performed at a 95\% confidence level with a 5\% margin of error via snowball sampling, which is a non-random sampling technique. Incomplete and unsuitable questionnaires were eliminated from the study.

The universe of the study consisted of large enterprises registered to the Gaziantep Chamber of Industry and Commerce and the sampling of the study was comprised of 46 firms. A total of 108 questionnaires were distributed to the HR authorities and managers of the firms. One-hundred questionnaires were considered appropriate for analysis after the incomplete and unsuitable questionnaires were eliminated. The demographic characteristics of the participants are shown in Table 1.

Table 1. Demographic characteristics of the participants $(\mathrm{n}=100)$

\begin{tabular}{ll} 
Gender & Men: 72 \\
& Women: 28 \\
\hline \multirow{2}{*}{ Marital Status } & Single: 32 \\
& Married: 60 \\
& Missing Data: 8 \\
\hline Age & Mean: 30,66 SD:7,599 \\
\hline \multirow{3}{*}{ Education Level } & High School: 32 \\
& $\begin{array}{l}\text { Associate Degree: } 32 \\
\text { Bachelor's Degree: } 34 \\
\text { Graduate Degree: } 2\end{array}$ \\
\hline
\end{tabular}

A majority of the participants consisting of HR managers were male and married. The average age of these participants was found out to be 30.66. The participants with a high school, associate degrees and bachelor's degree education level were nearly equally distributed within the sample. Only two participants with graduate degrees were present in the sample.

\section{FINDINGS}

In order to test the research hypotheses, primarily factor analysis was applied to the Scale of the Factors Affecting the Motivation of Generation Y. As a result, the sub dimensions of the factors were achieved. The coefficients obtained as a result of the Kaiser-Meyer-Olkin $(0,649)$ and Barlett's (sig. $p \leq 0,05$ ) tests indicated that the data set was sufficient for factor analysis. The values and factor loads are given in Table 2.

As a result of the descriptive factor analysis, the sub-dimensions were determined as: (1) work/life balance, training opportunities and team work, (2) salary and incentives, (3) leadership and mentoring programs and (4) taking responsibility. Regression analysis was used to test the research hypotheses formed regarding the measurement of the effects of the sub dimensions achieved as the result of the factor analysis on the strategies for the recruitment and retention of Generation Y. 
Table 2: Factor analysis of the Scale of the Factors that Affect the Motivation of Generation $\mathrm{Y}$

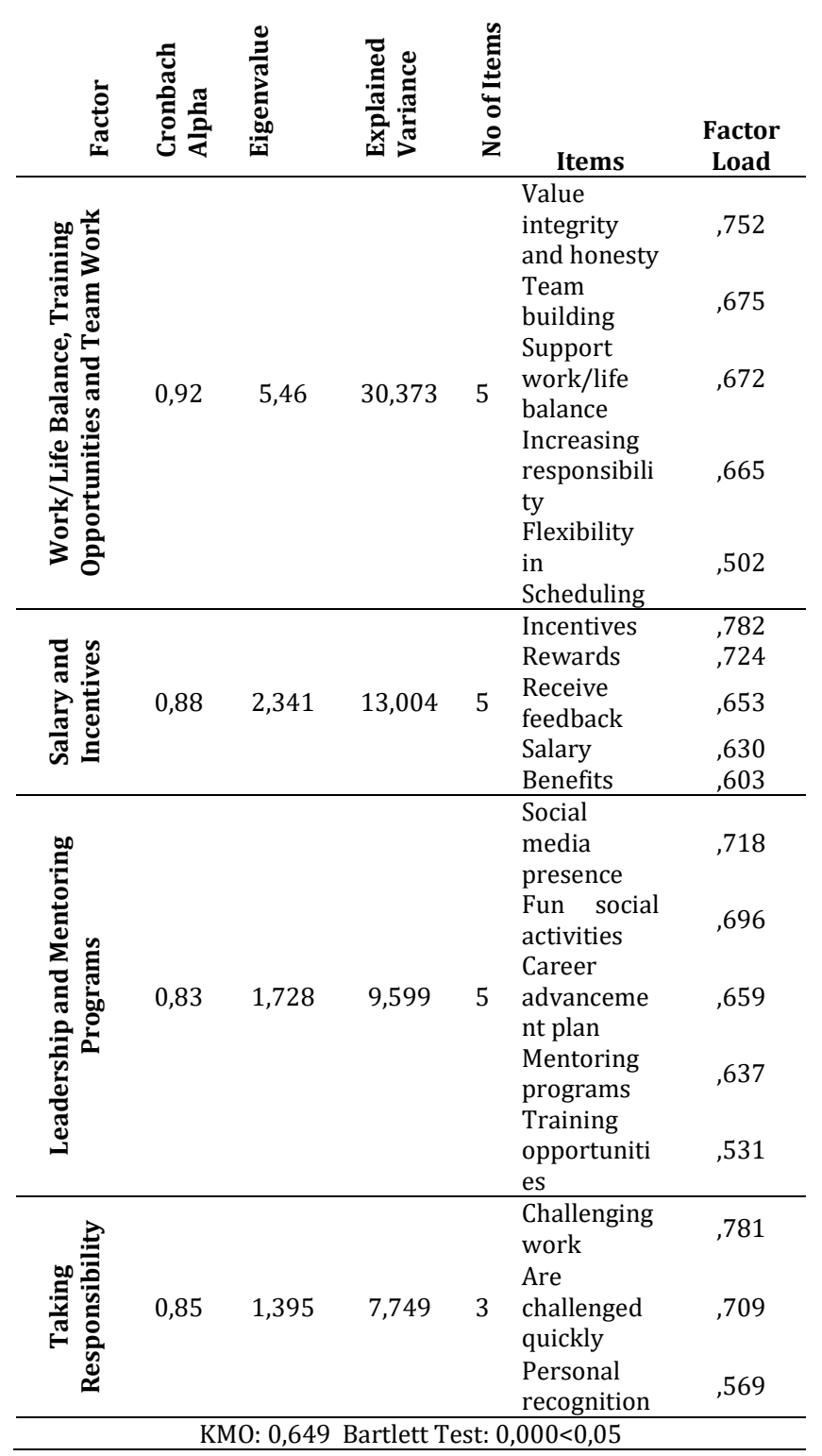

H1= Sub-dimensions of the Scale of the Factors that Affect the Motivation of Generation $Y$ affect the strategies for the recruitment of Generation $Y$

The significance level of the regression analysis was examined via ANOVA and it was concluded that the data were sufficient for the regression analysis. In order to determine which of the independent variables affected the dependent variable, the significance of the sub-dimensions was examined. As a result, three independent variables were determined to affect the recruitment strategies. Thus, $\mathrm{H} 1$ was partially accepted. The related values are demonstrated in Table 3.

Table 3: The impact of the factors that affect the motivation of generation $y$ on recruitment strategies

\begin{tabular}{|c|c|c|c|c|c|}
\hline & \multicolumn{2}{|c|}{$\begin{array}{l}\text { Unstandardized } \\
\text { Coefficients }\end{array}$} & $\begin{array}{l}\text { Standar } \\
\text { dized } \\
\text { Coefficie } \\
\text { nts }\end{array}$ & \multirow{2}{*}{$\mathbf{t}$} & \multirow{2}{*}{ Sig } \\
\hline & B & $\begin{array}{r}\text { Std. } \\
\text { Error }\end{array}$ & Beta & & \\
\hline (Constant) & 1,744 & ,537 & & 3,247 & ,002 \\
\hline $\begin{array}{l}\text { Work/life } \\
\text { balance, training } \\
\text { opportunities and } \\
\text { team work }\end{array}$ & 493 & 146 & 389 & 3,380 & 001 \\
\hline $\begin{array}{ll}\text { Salary } & \text { and } \\
\text { incentives } & \end{array}$ &,- 141 & 129 &,- 111 & $-1,095$ & ,276 \\
\hline $\begin{array}{l}\text { Leadership and } \\
\text { mentoring } \\
\text { programs }\end{array}$ & 380 & 113 & ,355 & 3,355 & ,001 \\
\hline $\begin{array}{l}\text { Taking } \\
\text { responsibility }\end{array}$ &,- 229 & 103 &,- 229 & $-2,233$ & ,028 \\
\hline $\begin{array}{l}\text { Anova F Value: } 8,876 \\
\text { Adjusted R2: } 0,241\end{array}$ & & $\begin{array}{l}\text { Anova } \\
\text { Durbir }\end{array}$ & $\begin{array}{l}\text { Sig Value: } \\
\text { Watson: }\end{array}$ & $\begin{array}{l}, 000<0 \\
674\end{array}$ & \\
\hline
\end{tabular}

The findings suggested that while the salary and incentives variable was not significant for the regression equation, the taking responsibility sub-dimension had a negative effect on the dependent variable. The work/life balance, training opportunities and team work sub-dimension $(B=0,493)$ was the first most effective variable, while the leadership and mentoring programs sub-dimension $(B=0,38)$ was the second most effective. It can be said that, any improvements applied to the motivation increasing factors present in the sub dimensions of work/life balance, training opportunities and team work and leadership and mentoring programs shall positively affect the strategies used for the recruitment of Generation Y. Similarly, an improvement applied to the motivation increasing factors present in the sub dimension of taking responsibility shall negatively affect the strategies used for the recruitment of Generation Y.

H2= Sub-dimensions of the Scale of the Factors that Affect the Motivation of Generation $Y$ affect the strategies for the retention of generation $Y$

The significance level of the regression analysis was examined via ANOVA for this hypothesis 
also and it was concluded that the data were sufficient for the regression analysis. In order to determine which independent variables affected the dependent variable, the significance of the sub-dimensions was examined. As a result, it was determined that two independent variables affected the retention strategies. Thus, $\mathrm{H} 2$ was partially accepted. The related values are demonstrated in Table 4.

Table 4. The impact of the factors that affect the motivation of generation $\mathrm{y}$ on retention strategies

\begin{tabular}{|c|c|c|c|c|c|}
\hline & \multicolumn{2}{|c|}{$\begin{array}{l}\text { Unstandardized } \\
\text { Coefficients }\end{array}$} & \multirow{2}{*}{$\begin{array}{r}\begin{array}{c}\text { Standardized } \\
\text { Coefficients }\end{array} \\
\text { Beta }\end{array}$} & \multirow{2}{*}{$t$} & \multirow{2}{*}{ Sig } \\
\hline & B & $\begin{array}{r}\text { Std. } \\
\text { Error }\end{array}$ & & & \\
\hline (Constant) & 1,800 & ,588 & & 3,059 & ,003 \\
\hline $\begin{array}{l}\text { Work/life } \\
\text { balance, training } \\
\text { opportunities } \\
\text { and team work }\end{array}$ & 439, & 160, & 337, & 2,751 & ,007 \\
\hline $\begin{array}{ll}\text { Salary } & \text { and } \\
\text { incentives }\end{array}$ &,- 173 & 141, &,- 132 & $-1,22$ & ,225 \\
\hline $\begin{array}{l}\text { Leadership and } \\
\text { mentoring } \\
\text { programs }\end{array}$ & 274 & 124, & 249, & 2,209 & ,030 \\
\hline $\begin{array}{l}\text { Taking } \\
\text { responsibility }\end{array}$ &,- 107 & 112, &,- 104 &,- 951 & ,344 \\
\hline $\begin{array}{l}\text { Anova F Value: } 4,9 \\
\text { Adjusted } \mathbf{R}^{2}: 0,138\end{array}$ & & $\begin{array}{l}\text { Anov } \\
\text { Durb }\end{array}$ & $\begin{array}{l}\text { a Sig Value: } 0,0 \mathrm{C} \\
\text { in Watson: } 1,60\end{array}$ & $1<0,05$ & \\
\hline
\end{tabular}

According to the findings of the analysis, the salary and incentives variable and the taking responsibility sub-dimension were not significant for the regression equation. The dependent variable was most affected by the work/life balance, training opportunities and team work sub-dimension $(B=0,439)$ and the leadership and mentoring programs subdimension $(B=0,274)$. Accordingly, it can be said that any improvements applied to the motivation increasing factors present in the sub dimensions of work/life balance, training opportunities and team work and leadership and mentoring programs shall positively affect the strategies used for the recruitment of Generation Y.

\section{DISCUSSION AND CONCLUSION}

The personality traits, life styles, expectations and many other characteristics of Generation $Y$, who constitute the majority of the current labor market, are remarkably different from those of other generations. Even if it is harder to work with Generation $Y$ compared to previous generations, firms both try to find ways to motivate this generation and also develop many strategies to benefit from their skills and qualifications. In this study, the effects of the factors affecting the motivation of Generation $Y$ on the strategies of recruitment and retention of Generation Y were investigated. In order to test the research hypotheses formed within this scope, multiple regression analysis was performed.

The first hypothesis of the study, "Subdimensions of the factors that affect the motivation of Generation Y affect the strategies for the recruitment of Generation Y" was partially accepted. According to the results of the regression analysis, the work/life balance, training opportunities and team work subdimension affected the strategies for the recruitment of Generation Y. This finding was in line with the literature. The studies of Roy and Kreiss (2011) and Yeaton (2008) determined that the work/life balance variable, which is one of the fundamental motivation factors of Generation Y, positively affected the strategies for the recruitment of Generation Y. According the findings of the present study, the training opportunities varies, which is within the same sub dimension as work/life balance, also affected the strategies for the recruitment of Generation Y. As the most educated generation, Generation Y, places great importance on training opportunities when choosing jobs, thus, training becomes an important motivation factor in the strategies for the recruitment of this generation. According to the Deloitte Survey (2009) report, 63.5\% of the participants chose the opportunities of improvement factor as the factor that they give the highest importance to when choosing jobs, which supports the finding of the present study. In addition, Generation $\mathrm{Y}$ is more eager, compared to other generations, in terms of team work and sees this as a motivation factor. In their studies VanHecke (2006), and Oblinger and Oblinger (2005) determined that team work positively affected the strategies for the 
recruitment of Generation Y. This finding was in line with the findings of the present study.

It was also determined that the leadership and mentoring programs variable had a positive effect on the strategies for the recruitment of Generation Y, which supports the literature. According to D'Netto (2011), organizations should provide opportunities such as on the job training, work rotation, counseling, and mentoring etc. to Generation Y employees in order to increase their recruitment, retention and motivation.

The present study found that the taking responsibility sub-dimension negatively affected the strategies for the recruitment of Generation Y. This result contradicted the literature. In their study, Martin and Tulgan (2001) stated that Generation Y added value to organizations and wanted to take on responsibility to contribute to the organizations. Additionally, according to Martin (2005) and SHRM (2009), Generation Y employees see increasing responsibility not as a burden to be avoided but as an opportunity to prove their abilities.

The second hypothesis of the study, "the sub dimensions of the factors effecting the motivation of Generation $Y$ affect the strategies for the retention of Generation Y" was partially accepted. According to the findings, the worklife balance, opportunities of training, and team work and leadership and mentoring programs sub dimensions positively affected the strategies for the retention of Generation Y.

The factors positively affecting the recruitment strategies in the first hypothesis, were found to also positively affect the retention strategies in the second hypothesis. Various studies in the literature, suggested that the motivation factors present in the work-life balance, training opportunities and team work sub dimension and the leadership and mentoring programs sub dimension should be used as a strategy by the employers wishing to retain Generation Y (Roy and Kreiss, 2011; Yeaton,
2008; Reynolds et al., 2008; Behrstock and Clifford, 2009; Zemke et al., 2000).

Generation $Y$ is significantly different from previous generations. Generation Y employees do not wish to work on hard or boring jobs. They prefer jobs that are different and make them feel that they are a part of the decisionmaking processes. Generation Y employees do not perceive the work done as an investment for the future of the company as previous generations did, instead they wish to collect the rewards of the work they perform immediately via various opportunities such as independence, flexible working hours, comfortable clothing and enjoyable work environment. In addition, Generation $\mathrm{Y}$ employees wish to know how they shall enter the business, how they can be included in decision making processes and whether their opinions are valued or not. They wish to be comfortable and work in jobs where career opportunities are plentiful. If businesses can provide these opportunities to Generation $Y$ employees, they can also benefit from their skills that are superior to the previous generations.

In this study, in order to determine the effects of the factors affecting the motivation of Generation $\mathrm{Y}$ on the strategies for their recruitment and retention, information was collected from HR managers. In future studies, the data can be collected from Generation Y employees themselves and the factors that increase their motivation can be updated. Furthermore, as the Generation Y employees of today shall be the managers of the future, they shall apply motivation increasing factors to the Generation Z employees, which are the next generation. Therefore, in future studies, the recruitment and retention strategies Generation Y managers apply to Generation Z employees and the motivation increasing factors affecting the said strategies can be studied. 


\section{REFERENCES}

ALS, M. (2008), "Recruiting and Retaining Generation Y: A New Workforce", Unpublished master's thesis, Aalborg University, Denmark.

ARMAN, A. (2013), "Yaşasın Y Kuşağı”, Hürriyet, 9 June, http://www.hurriyet.com.tr/yazarlar/234657 15.asp. (9.12.2013).

BEHRSTOCK, E., CLIFFORD, M. (2009). Leading gen y teachers: emerging strategies for school leaders, National Comprehensive Center for Teacher Quality, Washington, DC.

BLAIN, A. (2008), "The millennial tidal wave: five elements that will change the workplace of tomorrow", Journal of the Quality Assurance Institute, 22(2), 11-13.

BROADBRIDGE, A. M., MAXWELL, G. A., OGDEN, S. M. (2007), "Experiences, perceptions and expectations of retail employment for generation $y^{\prime \prime}, \quad$ Career Development International, 12(6), 523-544.

BROWN, S., CARTER, B., COLLINS, M., GALLERSON, C., GIFFIN, G., GREER, J., GRIFFITH, R., JOHNSON, E., RICHARDSON, K. (2009), "Generation y in the workplace", The Bush School of Government \& Public Service: Texas A\&M University, http://bushdev.tamu.edu/research/capstones /mpsa/projects/2009/2009GenerationYinthe Workplace.pdf (28.05.2014).

BUAHENE, A. K., KOVARY, G. (2003), "The road to performance success: understanding and managing the generational divide", n-gen People Performance Inc., http://www.ngenperformance.com/pdf/white / ManagingGenDivide.Overview.pdf (28.05.2014).

CHAO, D.G., GARDNER, D. P. (2008). "Young Adults at Work: What They Want, What They Get and How to Keep Them", Maynard: MonsterTRAK,

http://ceri.msu.edu/publications/pdf/yadults wk3-26-09.pdf (13.06.2017).
CHEESE, P. (2007), "The abc of generation y", Director, 61(5), 33.

CHESTER, E. (2002), Employing generation why?, Tucker House Books, Lakewood.

COLE, G., SMITH, R., LUCAS, L. (2002), "The debut of generation $\mathrm{y}$ in the American workforce", Journal of Business Administration, 1(2), 1-10.

CRAMPTON, S. M., HODGE, J. W. (2009), "Generation y: unchartered territory", Journal of Business and Economics Research, 7(4), 1-6.

CRUZ, C. S. (2007), "Gen y: how boomer babies are changing the workplace", Hawaii Business, http://www.hawaiibusiness.com/HawaiiBusiness/May-2007/Gen-Y/. (16.12.2013).

DATTA GUPTA, N., KRISTENSEN, N. (2008), "Work environment satisfaction and employee health: panel evidence from Denmark, France and Spain", The European Journal of Health Economics, 9(1), 51-61.

DELOITTE (2005), "Connecting across the generations in the workplace: what business leaders need to know to benefit from generational differences", Talent Market Series Vol. 1, http://blog.penelopetrunk.com/wpcontent/uploads/2007/07/deloittegenerations.pdf. (18.01.2014).

DELOITTE (2007), "Generation y. moving with the times", Deloitte, http://www.deloitte.com/assets/DcomUnited Kingdom/Local\%20Assets/Documents/Servic es/Tax/UK_Tax_MTF_Movingwiththetimes.pdf, (28.05.2014).

DELOITTE (2009), "Generation y: powerhouse of the global economy", Deloitte, http://www.deloitte.com/assets/DcomUnited States/Local\%20

Assets/Documents/us_consulting_hc_Generati onY_Snapshot_041509.pdf, (05.12.2013).

D'NETTO, B. (2011), “Generation y: human resources management implications", 
http://www.wbiconpro.com/452-Brian.pdf (28.05.2014).

DULIN, L. (2008), "Leadership preferences of generation y cohort. a mixed-methods investigation", Journal of Leadership Studies, 2(1), 43-59.

FELIX, S. (2007), "A flexible workplace", Benefits Canada. 31(6), 16-20.

FOX, A. (2011), "Mixing it up", HR Magazine, 56(5), 22.

GLASS, A. (2007), "Understanding generational differences for competitive success", Industrial and Commercial Training, 39(2), 98-103.

GLOBAL WORKPLACE INNOVATION (GWI) (2010). "Generation $y$ and the workplace: annual report 2010", http://www.gbcsa.org.za/wpcontent/uploads/2013/06/NZGBC-Gen-Y-andThe-Workplace-Annual-Report-2010.pdf (12.06.2016).

HART, K. A. (2006), "Generations in the workplace: finding common ground", MLO: Medical Laboratory Observer, 37(10), 26-27.

HASTINGS, R. (2008), "Millennials expect a lot from leaders", HR Magazine, 53(1), 30.

HEINIG, M. J. (2009), “Breastfeeding promotion for generations $\mathrm{x}$ and $\mathrm{y}$ : why the old ways won't work", Journal of Human Lactation, 25, 263265.

HEWLETT, S. A., SHERBIN, L., SUMBERG, K. (2009), "How Gen Y and Boomers will reshape your agenda", Harvard Business Review, 87(78), 71-6.

HOFF, J. (2010), “Generational Differences in Work Preferences", Unpublished master's thesis, Twente University, Netherlands.

http://www.capital.com.tr/ynin-pesindehaberler/18309.aspx. (30.09.2013).

http://www.cargill.com.tr/wcm/groups/publi c/@csf/@turkey/documents/document/na30 56107.pdf. (7.10. 2013).
HULETT, K. J. (2006), "They are here to replace us: recruiting and retaining millennials", Journal of Financial Planning, 17.

HUYBERS, C. M. (2011), "The Recruitment and Retention of Generation Y", Unpublished master's thesis, The Graduate School University of Wisconsin-Stout, Menomonie.

JOKELA, M. (2012), "Relationship between Perceived Organizational Support and Willingness to Pursue a Career in the Hospitality Industry", Unpublished master's thesis, Applied Sciences University, Finland.

JONES, B., BROWN, S. P., ZOLTNERS, A. A., WEITS, B. A. (2005), "The changing environment of selling and sales management", Journal of Personal Selling \& Sales Management, 25 (2), 105-111.

KANDELOUSI, N. S., SEONG, N. K. (2011), "Retention of generation y's insurance agent: mediating role of communication satisfaction an empirical study", Global Journal of Management and Business Research, 11(6), 1929.

KAREFALK, A., PETTERSSON, M., ZHU, Y. (2007), "How to Motivate Generation $Y$ with Different Cultural Backgrounds: A Cross-Cultural Comparison between China and Sweden", Research Report, Kristianstad University, November.

KELEŞ, H. N. (2011), "Y kuşağı çalışanlarının motivasyon profillerinin belirlenmesine yönelik bir araștırma", Organizasyon ve Yönetim Bilimleri Dergisi, 3 (2), 129-139.

KIM, H., KNIGHT, D. K., CRUTSINGER, C. (2009), “Generation y employees' retail work experience: the mediating effect of job characteristics", Journal of Business Research, 62(5), 548-556.

LANCASTER, L. C. (2004), "When generations collide: how to solve the generational puzzle at work", Management Forum Series, 17 March 2004.

LOWE, D., KENNETH, J. L., WILSON, T. (2008), "Solutions for retaining generation y employees 
in the workplace", Business Renaissance Quarterly, 3(3), 43-57.

LUSCOMBE, J., LEWIS, I., BIGGS, H. C. (2013), "Essential elements for recruitment and retention: generation y", Educating + Training, 55(3), 272-290.

MARTIN, C. A. (2005), "From high maintenance to high productivity: what managers need to know about generation y", Industrial and Commercial Training, 37(1), 39-44.

MARTIN, C. A., TULGAN, B. (2001), Managing generation $y$ : global citizens born in the late seventies and early eighties, HRD Press, Inc., Canada.

MARTIN, C. A., TULGAN, B. (2006), Managing the generation mix: from urgency opportunity. (2nd Ed.), HRD Press, Inc., Canada.

MCCRINDLE RESEARCH (2006), "New generations at work: attracting, recruiting, retraining \& training generation $\mathrm{y}^{\prime \prime}, \mathrm{McC}$ rindle, http://www.mccrindle.com.au/wp_pdf/NewG enerationsAtWork.pdf. (1.10.2013).

MEIER, J., CROCKER, M. (2010), “Generation y in the workforce: managerial challenges", The Journal of Human Resource Adult Learning, 6(1), 68-78.

MONSTERTRAK RESEARCH (2008), "Young adults at work: what they want, what they get and how to keep them", MonsterTrak, http://www.wwu.edu/careers/docs/Resource _YoungAdultsatWork.pdf . (28.01.2014).

MUKUNDAN, $\quad$ S., $\quad$ DHANYA, M., SARASWATHYAMMA, K. P. (2013), "A study on the conflict resolution styles of generation $y$ students in Indian context", International Journal of Global Business, 6(1), 81-90.

MURPHY, S. A. (2007), "Leading a multigenerational workforce", $N W$, Washington: AARP project, http://assets.aarp.org/www.aarp.org_/cs/mis c/leading_a_multigenerational_workforce.pdf . (27.09.2013).

NAID00, N. (2010), "Defining the employee value proposition for employees in old mutual
South Africa: a generational perspective", Research Report, The Graduate School of Business University of Cape Town, Cape Town, December.

\section{NAS RECRUITMENT COMMUNICATIONS} (2006), "Generation y: the millennials. ready or not, here they come", Permanent Such Group, http://www.permanentsearch.com/designedit /upload/GenerationY.pdf. (5.06.2014).

NAS RECRUITMENT COMMUNICATIONS (2007), "Recruiting and managing the generations",

http://www.nasrecruitment.com/uploads/file s/recruiting-managing-the-generations-whitepaper-65.pdf . (5.06.2014).

NICHOLAS, A. (2008), "Preferred learning methods of the millennial generation", Salve Regina University, http://digitalcommons.salve.edu/cgi/viewcon tent.cgi?article $=1017 \&$ context=fac_staff_pub. (24.01.2019).

OBLINGER, D. G., OBLINGER, J.L. (2005), "Educating the net generation", https://net.educause.edu/ir/library/pdf/pub7 101.pdf. (19.12.2013).

OLIVER, D. (2006), "An expectation of continued success: the work attitudes of generation y", Labour \& Industry: A Journal of The Social and Economic Relations of Work, 17(1), 61-84.

REEVES, T. C., OH, E. (2008), "Handbook of research on educational communications and technology: a project of the association for educational communications and technology", Spector, J. M., Merrill, M. D., Merrienboer, J. V. and Driscoll, M. P. (Eds.), Generational differences, Lawrence Erlbaum Associates Taylor \& Francis Group, New York, pp. 295-303 REYNOLDS, L., BUSH, E. C., GEIST, R. (2008), "The gen y imperative", Communication World, 25(3), 19-22.

RHI SURVEY (2007), "Survey generation y: a new generation in the workforce", Robert Half, http://www.slideshare.net/sonvde01/robert- 
half-generation-y-white-paper-def. (06.01.2019).

RICKS, R. S. (2010), “Managing Generation $Y$ in a Multigenerational Workplace", Unpublished master's thesis, The University of Texas at Austin, Austin.

ROLLSJÖ, A. (2008), "Attraction and Retention of Generation $Y$ Employees", Unpublished master's thesis, Baltic Business School, Kalmar University, Sweden.

ROY, J. G., KREISS, S. (2011), "Ten tips for retaining the next generation", Oil and Gas Journal, 109 (19A), 11-12.

SALT, B. (2007), "Beyond the baby boomer: the rise of generation $\mathrm{y}$ : opportunities and challenges for the funds management industry." Investment Management \& Funds, Zurich, Switzerland: KPMG International, https://www.kpmg.com/CN/en/IssuesAndIns ights/ ArticlesPublications/Documents/risegeneration-y-0-0706.pdf . (05.01.2014).

SAYERS, R. (2007), "The right staff from $x$ to $y$ : generational change and professional development in future academic libraries", Library Management, 28(8/9), 474-487.

SCHLITZKUS, L. L., SCHENARTS, K. D., SCHENARTS, P. J. (2010), "Is your residency program ready for generation y", Journal of Surgical Education, 67(2), 108-111

SENBIR, H. (2004), Z son insan mı?: z kuşağı ve sonrasına dair düşünceler. Okuyan Us Yayın Eğitim Danışmanlık Tıbbi Malzeme ve Reklam Hizmetleri San. Tic. Ltd. Şti, İstanbul.

SHRM (2009), "The multigenerational workforce: opportunity for competitive success", Society For Human Resource Management,

https://www.shrm.org/ResourcesAndTools/h r-topics/employee-relations/Documents/090027_RQ_March_2009_FINAL_no\%20ad.pdf (27.01.2019).

SPIRO, C. (2006), "Generation $y$ in the workplace", Workplace Transformation, http://www.cioindex.com/nm/articlefiles/64 130-UnderstandingGenY.pdf. (18.12.2018).

SRNIVASAN, V. (2012), "Multi generations in the workforce: building collaboration", IIBM Management Review, 24, 48-66.

SULLIVAN, S. E., FORRET, M. L., CARRAHER, S.M., MAINIERO, L. A. (2009), "Using the kaleidoscope career model to examine generational differences in work attitudes", Career Development International, 14(3), 284302.

THE MILLENNIAL IMPACT REPORT (2013), "The 2013 Millennial 2013 Impact Report", http://www.themillennialimpact.com/researc h\# researchemail. (28.01.2014).

TOLBIZE, A. (2008), "Generational differences in the workplace", working paper, Research and Training Center on Community Living, University of Minnesota, Minnesota, 16 August.

TWENGE, J. M., CAMPBELL, S. M. (2008), "Generational differences in psychological traits and their impact on workplace", Journal of Managerial Psychology, 23(8) , 862-877.

TWENGE, J. M., CAMPBELL, S. M., HOFFMAN, B. J., LANCE, C. E. (2010), "Generational differences in work values: leisure and extrinsic values increasing, social and intrinsic values decreasing", Journal of Management, 36(5), 1117-1142.

VALLEY, P. M. (2010), “Generation Y and Vocal Fry", Unpublished master's thesis, Virginia Commonwealth University Richmond, Virginia.

VAN HECKE, J. R. (2006), "Serving the millennial student: how far should we go?", http://www.nyu.edu/frn/publications/millen nial.student/ VanHecke\%20Keynote.html. (18.12.2013).

YAN, S. (2006), "Understanding generation y", The Oberlin Review, http://www.oberlin.edu/stupub/ocreview/20 06/12/08/features/Understanding_Generatio n_Y.html. (02.11.2018). 
YEATON, K. (2008), "Recruiting and managing the 'why?' generation: gen $\mathrm{y}^{\prime}$, The CPA Journal, $1,68-72$.

YÜKSEKBILGILI, Z. (2013), "Türk tipi y kuşağı”, Elektronik Sosyal Bilimler Dergisi, 12(45), 342353.

ZEMKE, R., RAINES, C., FILIPCZAK, B. (2000), Generations at work: managing the clash of veterans, boomer, xers, and nexters in your workplace, American Management Association, New York, NY.

ZHAO, H. (2006), "Expectations of recruiters and applicants in large cities of china", Journal of Managerial Psychology, 21(5), 459-475. 